Al Maal : Journal of Islamic Economics and Banking

http://jurnal.umt.ac.id/index.php/jieb

E-ISSN : $\quad 2580-3816$

Vol : 3 No. 1 Bulan Juli Tahun 2021

Hlm : $\quad 64-83$

DOI : $\quad$ : 10.31000/almaal.v3i1.4587

\title{
Strategi Pengelolaan Wakaf Produktif Dalam Rangka Pemberdayaan Ekonomi Umat Pada Wakaf Produktif Dompet Dhuafa Banten
}

\author{
Robi Setiawan ${ }^{1 *}$, Tenny Badina ${ }^{2}$, Mohamad Ainun Najib ${ }^{3}$ \\ 1,2,3 Jurusan Ekonomi Syariah, Fakultas Ekonomi dan Bisnis, Universitas Sultan Ageng \\ Tirtayasa, Indonesia \\ *robisetiawan160198@gmail.com
}

\section{ABSTRACT}

This research is a descriptive qualitative research type. The population chosen was Dompet Dhuafa Banten officers. While the sample used to be researched were the branch manager of Dompet Dhuafa Banten, Fundraising manager, the person in charge of Dompet Dhuafa Farm, and two mustahik people as permanent beneficiaries. Based on the research results the productive waqf management strategy in DD Banten consists of 4 strategies, namely ; 1). Established Dompet Dhuafa Farm, 2). DD Farm management involves experts in the field of animal husbandry, 3). Development of livestock business units, 4). Improve human resource competence. The concept of empowering the people in DD Banten is by employing mustahik from the area around DD Farm to work at DD Farm, after being employed for 2 years they are independent. Then they get assistance in the from capital assistance, housing assistance, mentoring assistance and partnership assistance, in DD Banten has succeeded in improving the economy of the mustahik. But the management of productive waqf in DD Banten has opportunities and obstacles, both internal and external. DD Banten managed the opportunities for productive waqf management. Meanwhile, DD Banten has been able to anticipate and minimize the obtstacles.

Keywords: People Economic Empowerment; Management Strategies; Productive Waqf.

\section{ABSTRAK}

Penelitian ini adalah jenis penelitian kualitatif deskriptif. Populasi yang dipilih adalah petugas Dompet Dhuafa Banten. Sedangkan sampel yang digunakan untuk diteliti adalah Pimpinan Cabang Dompet Dhufa Banten, Manajer Fundraising, Penanggungjawab Dompet Dhuafa Farm, dan dua orang mustahik sebagai penerima manfaat tetap. Berdasarkan hasil penelitian bahwa strategi pengelolaan wakaf produktif di DD Banten terdiri dari 4 strategi yaitu, 1). Mendirikan Dompet Dhuafa Farm, 2). Pengelolaan DD Farm melibatkan ahli dibidang peternakan, 3). Pengembangan unit-unit bisnis peternakan, 4). Meningkatkan kompetensi sumber daya manusia. Adapun konsep pemberdayaan umat di DD Banten adalah dengan memperkerjakan para mustahik yang berasal dari daerah sekitar DD Farm untuk bekerja di DD Farm. Setelah dipekerjakan selama 2 tahun mereka dimandirikan. Ketika dimandirikan mereka mendapatkan bantuan berupa bantuan modal, bantuan pembangunan kandang, bantuan pendampingan, dan bantuan kemitraan. Pengelolaan wakaf produktif melalui program pemberdayaan ekonomi di DD Banten berhasil meningkatkan ekonomi para mustahik. Namun, pengelolaan wakaf produktif di DD Banten terdapat peluang dan hambatan baik internal maupun eksternal. Peluang-peluang dalam pengelolaan wakaf produktif sudah mampu dikelola dengan baik oleh DD Banten. Sedangkan hambatannya sudah mampu diantisipasi dan diminimalisir oleh DD Banten.

Kata kunci : Pemberdayaan Ekonomi umat; Strategi Pengelolaan; Wakaf Produktif. 


\section{Pendahuluan}

Indonesia merupakan negara berkembang (Developing Country) yang pada umumnya menghadapi berbagai permasalahan yang cukup pelik seperti ekonomi, kemiskinan, ketebelakangan dalam pendidikan, rendahnya kualitas sumber daya manusia dan masalah-masalah lain. Berbagai upaya telah dilakukan oleh pemerintah, namun hasilnya belum maksimal. Kebijakan pemerintah untuk mengatasi berbagai masalah ekonomi tersebut cenderung membuat negara kita bergantung kepada negara lain. Pada saat ini pemerintah sedang mencari jalan keluar untuk mengatasi berbagai masalah tersebut, khususnya masalah ekonomi yang melanda Indonesia (Nawawi, 2016).

Islam merupakan Agama yang paling banyak penganutnya memiliki beberapa lembaga yang diharapkan mampu membantu pemerintah mewujudkan kesejahteraan sosial, salah satunya yaitu wakaf. Wakaf merupakan salah satu lembaga sosial Islam yang erat kaitannya dengan sosial ekonomi masyarakat. Walaupun wakaf merupakan lembaga Islam yang hukumnya sunah, namun lembaga ini dapat berkembang dengan baik karena lembaga ini memang sangat dirasakan manfaatnya bagi kesejahteraan umat hal ini bisa dilihat dari banyaknya tempat-tempat ibadah, sekolah-sekolah, rumah sakit dan lain-lain yang berasal dari harta benda wakaf (Nasution dan Hasanah, 2005:51).

Konsep pemberdayaan ekonomi merupakan bagian dari tujuan pembangunan ekonomi, yaitu meningkatkan taraf kesejahteraan, kualitas dan kelangsungan hidup dan memulihkan fungsi sosial dalam rangka mencapai kemandirian, meningkatkan ketahanan, kemampuan, kepedulian serta tanggung jawab sosial. Upaya meningkatkan kesejahteraan ekonomi umat merupakan bagian dari tanggung jawab bersama (Hadyantari, 2018). Ada beberapa aspek yang mempengaruhi dalam mencapai kesejahteraan salah satunya aspek ekonomi. Cara untuk mencapai tujuan itu bisa melalui pemberdayaan masyarakat sehingga masyarakatpun dapat merasakan manfaat dari kekuatan ekonomi secara merata, dengan meratanya kesejahteraan ekonomi maka jurang pemisah antar kelompok masyarakat yang kaya dan kelompok yang miskin akan dapat diperkecil.

Menurut data paling mutakhir yang dimiliki oleh direktorat pemberdayaan wakaf tahun 2020, jumlah aset tanah wakaf di Indonesia seluas 51.258.62 Ha. Luas tanah tersebut tersebar pada 381.995 lokasi. Dari keseluruhan luas tanah tersebut yang sudah bersertifikat sebesar $61.12 \%$ dan yang belum bersertifikat sebesar $38.88 \%$. Namun, besar aset wakaf tersebut belum mampu membawa kesejahteraan bagi masyarakat Muslim di Indonesia. Berdasarkan data sistem informasi wakaf (SIWAK) tahun 2020 menunjukan aset tanah wakaf di Indonesia sebagian besar digunakan untuk masjid \& mushola (72.77\%), makam (4.45\%), sekolah (10.68\%), pesantren (3.49\%), sosial lainnya termasuk untuk pertanian, bisnis dan lain-lain (produktif) sebesar $(8.61 \%)$. 
Gambar 1. Gambar Pemanfaatan Tanah Wakaf di Indonesia

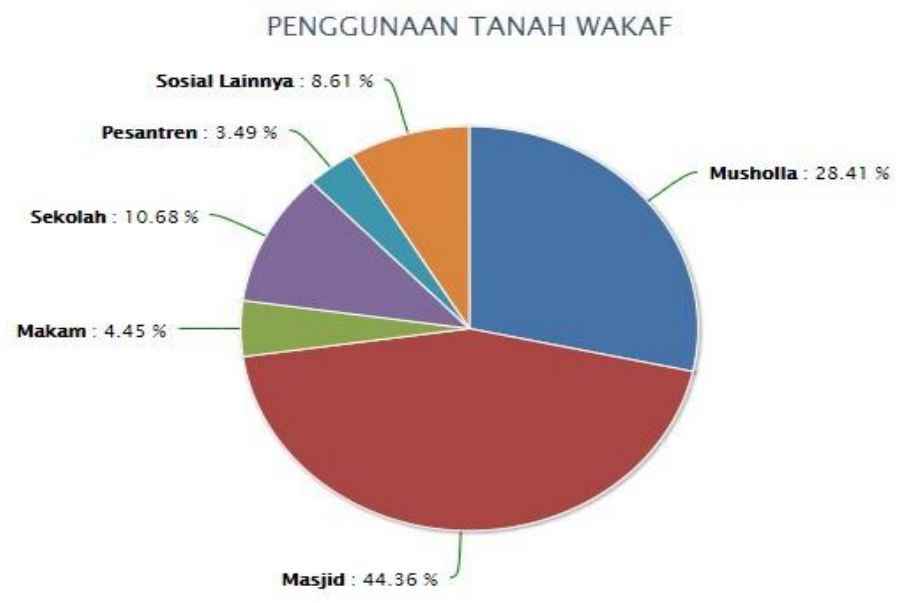

Sumber: Sistem informasi wakaf Tahun 2020

Dari data diatas penulis melihat bahwa sebagian besar pemanfaatan tanah wakaf di Indonesia masih belum mengarah pada manajemen produktif atau investasi wakaf. Jika aset tanah wakaf tersebut dikembangkan secara produktif yang mengarah pada peningkatan perekonomian masyarakat potensinya sangat besar yaitu sekitar $19.4 \%$ dari Produk Domestik Bruto (PDB) (Nizar, 2017). Potensi inilah yang belum dipahami secara lebih baik bagi pengambilan kebijakan perekonomian bangsa. Kekayaan tersebut belum menghitung potensi wakaf uang yang sedang dan akan terkumpul sebagai salah satu jenis wakaf likuid yang telah diatur dalam peraturan perundang-undangan wakaf.

Melihat perkembangan ekonomi yang cukup lamban timbullah keinginan yang kuat untuk mempercepat proses kebangkitan ekonomi umat pada akhirnya membuat Dompet Dhuafa Republika termotivasi untuk menggali potensi dana wakaf. Dompet Dhuafa meraih penghargaan dalam kategori wakaf, penghargaan yang diberikan tersebut karena Dompet Dhuafa Republika adalah sebagai pegiat dan pengelola wakaf yang baik. Melihat dari profil dan prestasi yang diraih oleh Dompet Dhuafa serta program-program yang dijalankan membuat penulis tertarik untuk melakukan penelitian terhadap strategi pengelolaan wakaf produktif yang dilakukan oleh Dompet Dhuafa dalam rangka pemberdayaan ekonomi umat. Jika program-program pengelolaan wakaf produktif yang ada di Dompet Dhuafa dijalankan dengan baik dan optimal maka dapat memberikan manfaat yang besar sehingga dapat membantu memperkecil angka kemiskinan dan pengangguran di Indonesia khususnya di Banten.

Berdasarkan pada permasalahan dan fakta yang terdapat di atas, maka penelitian ini bertujuan untuk menganalisis dan memaparkan Strategi Pengelolaan Wakaf Produktif Dalam Rangka Pemberdayaan Ekonomi Umat" (Studi Kasus : Wakaf Produktif Dompet Dhuafa Banten).

\section{KAJIAN LITERATUR Strategi}

Menurut Rangkuti, strategi adalah alat untuk mencapai tujuan. Ada beberapa pengertian strategi di dalam bukunya Rangkuti, salah satunya yaitu menurut Chandler (1962) mengatakan bahwa strategi adalah alat yang digunakan perusahaan untuk mencapai tujuan perusahaan dengan tujuan jangka panjang, program tidak lanjut, serta 
prioritas alokasi sumber daya (Rangkuti: 2014:3-4). Dari definisi diatas maka penulis dapat menyimpulkan bahwa strategi adalah alat untuk mencapai tujuan atau keungulan bersaing dengan melihat faktor eksternal dan internal suatu perusahaan/organisasi. Perusahaan/organisasi melakukan tindakan yang dapat menjadikan keuntungan, baik untuk perusahaan/organisasi maupun pihak lain.

\section{Fungsi dan Konsep Strategi}

Fungsi Strategi menurut Assauri (2013) fokus tujuan strategi adalah untuk menentukan proses rencana agar dapat mencapai tujuan dengan jangka waktu yang panjang. Strategi disusun agar dapat diaplikasikan secara efektif. Fungsi-fungsi strategi adalah sebagai berikut :

- Untuk mengkomunikasikan suatu maksud (visi) yang ingin dicapai kepada orang lain.

- Untuk menghubungkan kekuatan organisasi dengan peluang dari lingkungannya.

- Untuk menyelidiki adanya peluang baru

- Untuk menghasilkan sumber daya yang lebih banyak dari sekarang.

- Untuk mengkoordinasikan kegiatan untuk kedepannya.

- Untuk bereaksi atas aktivitas kedepannya.

Konsep strategi menurut Sopiah (2018) strategi didasarkan pada tiga konsep utama yaitu Competitive advanted, distinctive capability, strategic fit.

- Competitive advanced.Porter merumuskan dua jenis keunggulan kompetitif perusahaan, yaitu biaya rendah atau diferensiasi produk. Seperti inovasi, kualitas produk dan kepemimpinan harga.

- Distincrive capability. Konsep ini dikemukakan oleh Kay (1993) yaitu perusahaan lain tidak dapat melakukan replikasi dengan membangun karakter unik dalam hubungan yang dimilikinya dengan lingkungan eksternal (pemangku kepentingan) dan internal (pelanggan, pemasok, karyawan, pemegang saham, investor).

- Strategic Fit. Konsep ini menjelaskan tentang situasi yang terjadi ketika terget perusahaan atau produk dipandang sesuai dengan tujuan keseluruhan organisasi. Perusahaan mengembangkan bisnisnya dengan merger atau akuisisi.

\section{Pengertian Wakaf Produktif}

Wakaf dalam Bahasa Arab adalah isim mashdar dari kata وقف (waqafa). Menurut Al Zuhaili التوقف (al tahbis: menahan) serta التسبيس (al tasbil: menderma) adalah satu arti. Wakaf menurut bahasa adalah menahan dari tasharruf (Waluya, 2018).

Menurut Abdurrahman (1994) dalam Dini Handayani (2011:26) Pengertian wakaf yang ada seperti dikemukakan para pakar Hukum Islam pada prinsipnya memiliki persamaan dan perbedaaan. Persamaannya dari beberapa pengertian wakaf terletak pada pokok harta wakaf ('ainnya) harus tetap ada tidak boleh hilang ataupun berkurang, dengan 
keharusan 'ain dari wakaf tetap ada para pakar tersebut mengisyaratkan pentingnya pelestarian harta dengan menjaga keutuhannya sehingga dapat dimanfaatkan secara berulang-ulang. Sementara perbedaannya terletak pada kepemilikan harta setelah diwakafkan, sebagian mengatakan masih milik si wakif dan sebagian lagi mengatakan menjadi milik Allah atau menjadi milik penerima wakaf tersebut dan perbedaan tersebut juga terlihat pada harta wakaf, di mana harta wakaf untuk selama-lamanya atau dapat dipersewakan saja (sementara).

Muhammad Syafi'i Antonio mengatakan bahwa wakaf produktif adalah pemberdayaan wakaf yang ditandai dengan ciri utama, yaitu; pola manajemen wakaf harus terintegrasi, asas kesejahteraan nazir, dan asas transformasi dan tanggungjawab (Sirojudin, 2015:97). Munzir Qahaf mendefinisikan wakaf produktif dengan wakaf harta yang digunakan untuk kepentingan produksi, dimana harta wakaf dikelola untuk menghasilkan barang atau jasa kemudian dijual dan hasilnya dipergunakan sesuai dengan tujuan wakaf. Pengelolaannya bisa dilakukan melalui bidang pertanian, perindustrian, perdagangan dan bidang lainnya (Mubarok, 2013).

\section{Manajemen Wakaf Produktif}

Dalam perwakafan, pengelola wakaf atau nazir sangat membutuhkan manajemen dalam menjalankan tugasnya. Manajemen ini digunakan untuk mengatur kegiatan pengelolaan wakaf, menghimpun wakaf uang, dan menjaga hubungan baik antara nazir, wakif dan masyarakat (Rozalinda, 2015:72). Untuk itu, yang penting adalah nazir menguasai prinsip-prinsip manajemen yang meliputi: Pertama, tahapan fungsi manajemen, Kedua, manajemen fundraising, Ketiga, manajemen pengembangan, Keempat, manajemen pemanfaatan, Kelima, manajemen pelaporan.

\section{Aspek Pengelolaan Manajemen Wakaf}

Untuk meningkatkan dan mengembangkan aspek kemanfaatannya, tentu sangat berperan sentral adalah system manajemen pengelolaan yang diterapkan, hal tersebut bisa dilihat pada aspek-aspek pengelolaannya (Niryad, 2015). Terkait dengan pengelolaan wakaf secara produktif, ada beberapa aspek yang harus diperhatikan, aspek-aspek tersebuat akan dijelaskan sebagai berikut: Aspek Kelembagaan Wakaf, Pengelolaan Operasional, Kehumasan, Sistem Keuangan.

\section{Pemberdayaan Ekonomi}

Menurut Anwar (2007), dikutip oleh Hadyantari (2017) menyatakan bahwah pemberdayaan merupakan suatu kegiatan yang berkesinambungan, dinamis dan secara strategis mendorong keterlibatan semua potensi secara evolutif. Pemberdayaan ekonomi merupakan salah satu usaha memampukan dan memandirikan kehidupan perekonomian masyarakat tersebut. Masyarakat berperan penting dalam membangun kesejahteraan sosial. Keterlibatan masyarakat baik secara fisik, pemikiran, material maupun finansial diharapkan dapat meningkatkan rasa kebersamaan dan melalui proses dan hasil pembangunan yang ada (Adi, 2013).

Pemberdayaan ekonomi merupakan salah satu usaha memampukan dan memandirikan kehidupan perekonomian masyarakat tersebut. Masyarakat berperan penting dalam membangun kesejahteraan sosial. Keterlibatan masyarakat baik secara fisik, pemikiran, material maupun finansial diharapkan dapat meningkatkan rasa kebersamaan dan melalui proses dan hasil pembangunan yang ada (Adi, 2013). 
Pemberdayaan bertujuan untuk memunculkan potensi yang ada secara mandiri, memberikan kesempatan berusaha yang sama, memberikan modal sebagai dorongan, adanya kerjasama dan kemitraan kuat yang mendukungnya serta peningkatan akses sumber daya manusia dan sarana prasarana yang ada (Hadyantari, 2017).

\section{Indikator Pemberdayaan}

Terkait dengan kriteria keberhasilan yang digunakan untuk suatu proses evaluasi, Feurstein (1990) dalam Yulma (2016) mengajukan beberapa indikator yang perlu dipertimbangkan. Indikator di bawah ini adalah sembilan indikator yang paling sering digunakan untuk mengevaluasi keberhasilan suatu kegiatan pemberdayaan, yaitu : a). Indikator Ketersediaan, b). Indikator Relevansi, c). Indikator Keterjangkauan, d). Indikator Pemanfaatan, e). Indikator Cakupan, f). Indikator Kualitas, g). Indikator Upaya, h). Indikator Efisiensi, i). Indikator Dampak.

\section{Tujuan Pemberdayaan Masyarakat}

Tujuan Pemberdayaan Masyarakat. Tujuan yang ingin dicapai dari pemberdayaan menurut Sulistiyani (2004) dalam Sarinah dkk (2019) adalah: untuk membentuk individu dan masyarakat menjadi mandiri, meliputi mandiri berpikir, bertindak dan mengendalikan apa yang mereka lakukan.

\section{Metode Penelitian}

Penelitian ini menggunakan jenis penelitian lapangan dengan pendekatan kualitatif deskriptif. Pada penelitian ini, peneliti berusaha untuk mengkaji dan menjelaskan tentang "Strategi Pengelolaan Wakaf Produktif dalam Rangka Pemberdayaan Ekonomi Umat (Studi Kasus : Wakaf Produktif Dompet Dhuafa Banten). Lokasi dalam penelitian ini adalah di Dompet Dhuafa Banten yang merupakan salah satu lembaga amil zakat yang bertindak sebagai pengelola dalam mengelola wakaf produktif.

Data yang diperlukan dalam penelitian ini, berupa data langsung dari pengurus dan informasi mengenai program-program dari Dompet Dhuafa Banten, data penerimaan, data pendistribusian, data keuangan, dokumentasi, juga data dari media yang diterbitkan oleh Dompet Dhuafa Banten. Sumber datanya antara lain : 1. Data primer. Data primer adalah data yang berasal dari sumber yang asli dan dikumpulkan secara khusus untuk menjawab sebuah penelitian (Gunawan, 2013: 143). 2. Data sekunder adalah jenis data tambahan yang tidak diperoleh dari sumber utama. Data sekunder bersumber dari buku, jurnal, artikel, hingga penelitian sebelumnya. (Hakim, 2020).

Metode pengumpulan data yang dilakukan dalam penelitian ini adalah dengan cara observasi, wawancara, dan dokumentasi. Adapun analisis data dalam penelitian ini menggunakan teori Miles da Hubberman yang terdiri dari beberapa langkah yaitu: reduksi data, penyajian data, dan verifikasi data atau penarikan kesimpulan. Uji kredibilitas dalam penelitian ini adalah dengan menggunakan trangulasi teknik, triangulasi teknik berarti penulis menggunakan tiga teknik pengumpulan data mencari kelengkapan informasi yang diperoleh. 
Gambar 2. Gambar triangulasi dengan 3 teknik pengumpulan data

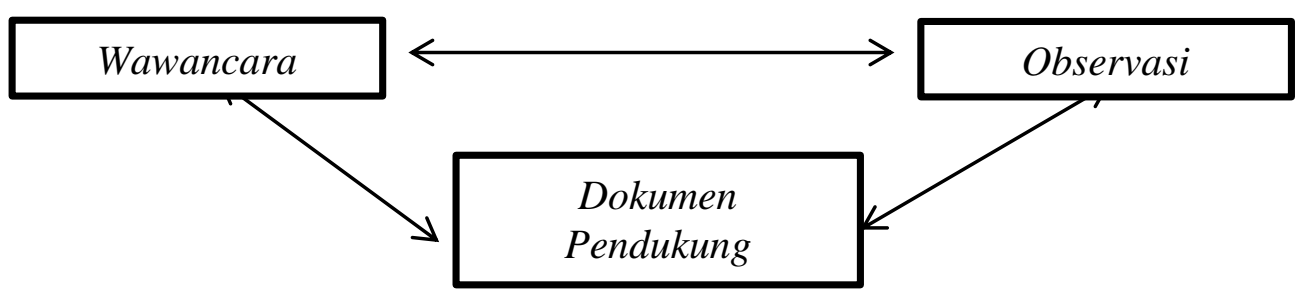

Sumber : Sugiyono, 2017

\section{Hasil dan PeMbahasan}

\section{Gambaran Umum Objek Penelitian}

Objek penelitian ini adalah Dompet Dhuafa Banten. Dompet Dhuafa Banten lahir bermula dari banyaknya fenomena kemiskinan yang membuat miris beberapa aktivis sosial di Banten. Sehingga pada tahun 2010 para aktivis sosial tersebut yang tergabung dalam yayasan lokal bernama Uswatun Hasanah. Pimpinan Moch. Najib \& Hasan Basri selaku inisiator pendiri Dompet Dhuafa Banten melakukan sinergi kerjasama bersama Dompet Dhuafa. Lalu digagaslah kolaborasi kegiatan sosial yang berbasis dana ZISWAF di wilayah Banten. Antara kedua lembaga tersebut dalam lembaga bernama Dompet Dhuafa Banten dengan harapan dapat memberikan solusi dan kontribusi positif bagi masyarakat miskin.

Tahun 2016 Dompet Dhuafa Banten mendapatkan izin dan rekomendasi dari Kementrian Agama Republik Indonesia Kantor Wilayah Kementrian Agama Provinsi Banten (Kanwil Kemenag Prov. Banten) sebagai Lembaga Amil Zakat (LAZ) skala nasional yang membuka cabang perwakilan di Banten yang berlokasi di Jl. Kyai H. Sokhari no.4C, Sumurpecung, Kec. Serang, Kota Serang, Banten 42118.

\section{Stategi Pengelolaan Wakaf Produktif di Dompet Dhuafa Banten}

Menurut Assauri (2013) fokus tujuan strategi adalah untuk menentukan proses rencana agar dapat mencapai tujuan dengan jangka waktu yang panjang. Strategi disusun agar dapat diaplikasikan secara efektif. Fungsi-fungsi strategi adalah sebagai berikut :

- Untuk mengkomunikasikan suatu maksud (visi) yang ingin dicapai kepada orang lain. b. Untuk menghubungkan kekuatan organisasi dengan peluang dari lingkungannya.

- Untuk menyelidiki adanya peluang baru.

- Untuk menghasilkan sumber daya yang lebih banyak dari sekarang.

- Untuk mengkoordinasikan kegiatan untuk kedepannya.

- Untuk bereaksi atas aktivitas kedepannya.

Adapun strategi yang dilakukan oleh Dompet Dhuafa Banten dalam melakukan pengelolaan wakaf produktif adalah sebagai berikut : 
- Mendirikan Dompet Dhuafa Farm. Berdasarkan hasil pengamatan penulis selama melakukan penelitian di DD Banten. Model wakaf produktif yang diterapkan di Dompet Dhuafa Banten merupakan model yang ada dalam teori model wakaf produktif menurut Handayani (2011) yaitu model wakaf produktif pengembangan usaha, dalam hal ini pengembangan usaha peternakan domba dan kambing atau sering di sebut dengan "DOKA" beserta unit-unit bisnis turunannya yang selanjutnya diberi nama "Dompet Dhuafa Farm". Wakaf produktif yang dikelola oleh DD Banten tersebut sangat produktif.

- Pengelolaan DD Farm melibatkan ahli bidang peternakan. Pengelolaan wakaf merupakan salah satu unsur yang penting dalam hal perwakafan. Baik tidaknya pengelolaan wakaf tersebut tergantung pada kemampuan pengelola wakaf. Apabila pengelola wakaf tidak cakap dalam mengelolanya maka dapat menyebabkan wakaf tersebut tidak optimal dalam meningkatkan perekonomian masyarakat.

Adapun penerapan strategi pengelolaan wakaf di Dompet Dhuafa Banten yaitu dengan merekrut pihak ketiga yakni orangnya yang ahli dibidangnya dalam hal ini orang yang ahli dalam bidang peternakan domba dan kambing. Setelah itu pihak ketiga bekerjasama dengan DD Banten untuk mengelola DD Farm. Dalam kerjasama tersebut DD Banten berperan sebagai supervisor artinya hal-hal yang berkaitan dengan manajerial dan keputusan-keputusan penting tetap menjadi kewenangan DD Banten. Akan tetapi dalam hal-hal yang berkaitan dengan teknis diserahkan kepada yang ahlinya yakni pihak ketiga, karena pihak ketiga lebih mengerti tentang kondisi dilapangan.

- Pengembangan unit-unit bisnis peternakan. Dompet Dhuafa Farm Banten merupakan sentra ternak yang dapat menghasilkan pengembangan unitunit bisnis. Karena dari hulu sampai hilir ragam bisnis yang bisa dikembangkan dari DD Farm itu bervariasi.

- Meningkatkan kompetensi sumber daya manusia. Peningkatan kompentensi sumber daya manusia (SDM) di lembaga Dompet Dhuafa menjadi sebuah hal yang harus dilakukan secara rutin, bahkan dalam satu bulan bisa diselenggarakan berkali-kali. Kompetensi juga menyangkut pengetahuan tentang bagaimana mengelola program pemberdayaan secara Syariah dan hal-hal ini intensif dilakukan oleh DD Banten. Dalam proses penguatan kompetensi SDM di DD Banten dilakukan baik dari internal ataupun dari eksternal. Dari internal Dewan Syariah sering mengadakan acara kajian syariah, kegiatan itu dilaksanakan bisa perminggu atau perbulan sehingga lembaga mengetahui tentang bagaimana mengelola wakaf produktif sesuai syariat. Sedangkan penguatan kompetensi dari eksternal karyawan DD Banten sering mengikuti pelatihan-pelatihan atau seminar-seminar yang diselenggarakan oleh lembaga atau instansi lain. Oleh karena itu wajar jika kemudian melihat para karyawan atau relawan DD Banten ini berada di tempat-tempat lain seperti di Baznas, BWI dan lain sebagainya. 
Pengaruh Strategi Pengelolaan Terhadap Jumlah Transaksi

Tabel 1. Tabel Data Penghimpunan Berdasarkan Jenis Transaksi

\begin{tabular}{llll}
\hline No & Jenis Dana & 2018 & 2019 \\
\hline 1 & Zakat Maal & $R p 1.442 .284 .912$ & $R p 1.589 .901 .601$ \\
2 & Zakat Fitrah & $R p 32.682 .000$ & $R p 41.518 .500$ \\
3 & Infak Sedekah & $R p 610.356 .813$ & $R p 481.376 .766$ \\
4 & Kurban & $R p 423.354 .002$ & $R p 687.252 .500$ \\
5 & Infak Tematik & $R p 116.466 .343$ & $R p 100.910 .130$ \\
6 & Infak Terikat & $R p 1.900 .000$ & $R p 116.100 .000$ \\
7 & Fidyah & $R p 8.535 .005$ & $R p 27.800 .000$ \\
8 & Wakaf & $R p 44.125 .000$ & $R p 180.054 .905$ \\
9 & Kemanusiaan & $R p 657.011 .656$ & $R p 510.646 .308$ \\
& Total Penghimpunan & Rp3.336.715.731 & $R p 3.735 .560 .710$ \\
\hline
\end{tabular}

Sumber : Dompet Dhuafa Banten, 2020

Tabel 2. Tabel Data Pendistribusian Berdasarkan Jenis Program

\begin{tabular}{llll}
\hline No & Nama Program & Tahun 2018 & Tahun 2019 \\
\hline 1 & Ekonomi & Rp237.243.266 & Rp118.612.068 \\
2 & Kesehatan & Rp8.038.800 & Rp79.074.712 \\
3 & Sosial & Rp1.297.290.861 & Rp1.937.330.459 \\
4 & Kemanusiaan & Rp332.357.043 & Rp1.502.419.539 \\
5 & Pendidikan \& Dakwah & Rp279.573.653 & Rp316.298.850 \\
& Total penyaluran & Rp2.154.503.623 & Rp3.953.735.631 \\
\hline \multicolumn{4}{r}{ Sumber : Dompet Dhuafa Banten, 2020 }
\end{tabular}

Total penghimpunan di atas menunjukan bahwa strategi pengelolaan dana ZISWAF dan dana lainnya, menunjukan hubungan antara penerapan strategi pengelolaan dengan jumlah himpunan setiap tahunnya. Dari jumlah dana himpunan dana ZISWAF dan dana lainnya setiap tahunnya mengalami peningkatan, sehingga dapat kita lihat bahwa strategi pengelolaan yang dilakukan oleh Dompet Dhuafa Banten sudah cukup optimal. Dimulai dari tahun 2018, dimana total penghimpunan sebesar Rp3.336.715.731 dengan total pendistribusian sebesar Rp2.154.503.623. Kemudian bertambah total penghimpunannya di tahun 2019 menjadi Rp3.735.560.710 dengan total pendistribusian sebesar Rp3.953.735.631. Hal ini membuktikan bahwa Dompet Dhuafa Banten memiliki potensi yang cukup besar dalam penghimpunan dana ZISWAF yang dikeluarkan oleh para muzakki dan donatur agar dapat dikelola dengan berbagai inovasi yang lebih baik lagi.

\section{Sistem Pemberdayaan Ekonomi Umat di DD Farm Banten}

Sebelum penulis menjelaskan terkait dengan pemberdayaan wakaf produktif di DD Farm Banten, penulis jelaskan terlebih dahulu sumber dana yang digunakan oleh DD Farm Banten. Untuk memudahkan dalam memahami alur sumber pendanaannya, maka penulis membuatnya dalam bentuk tabel dan kemudian mendeskripsikannya. 


\section{Sumber Dana Pemberdayaan Ekonomi di DD Farm}

\section{Gambar 3. Gambar Sumber Dana DD Farm}

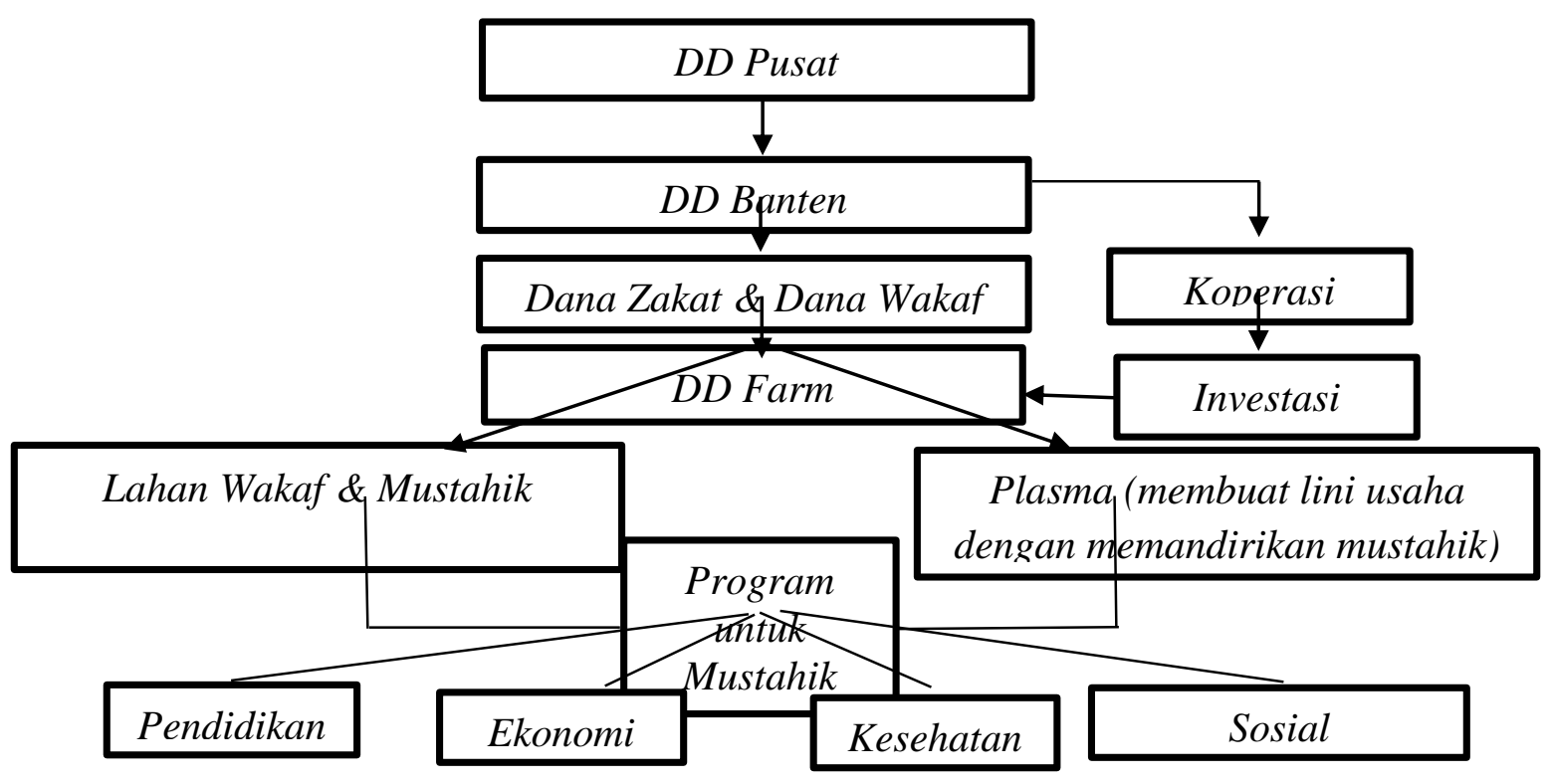

Sumber: Dompet Dhuafa Banten 2020

Berdasarkan tabel di atas dapat dipahami bahwa ada 3 sumber dana yang digunakan oleh DD Farm dalam melakukan pemberdayaan ekonomi umat, yaitu dana wakaf, dana zakat, dan dana investasi. Sumber dana dari DD Banten yaitu dana zakat dan wakaf, dan satu sumber dana dari investor. Untuk dana dari investor DD Banten tidak ikut intervensi tetapi ikut mencarikan investor, pada saat terjadinya kerjasama maka yang terlibat adalah pihak investor dengan pihak ketiga yakni koperasi, kemudian hasil pengelolaanya akan disalurkan untuk program-program mustahik.

Semua pengelolaan yang dilakukan adalah tentang bagaimana lembaga dan koperasi mencari sumber-sumber dana lain dari kejenuhan dana zakat dan wakaf, karena dana zakat dan wakaf itu terbatas, maka harus mencari sumber dana lain dari luar supaya program ini bisa berkepanjangan dan berkembang lebih besar, sehingga mustahik bisa berpenghasilan lebih besar, program yang dibuat akhirnya bisa membantu banyak orang, jika kurang kreatif dalam mencari sumber dana lain, maka program yang ada akan terhenti begitu saja dan dana zakat hanya akan disalurkan ke program ini saja, sementara banyak program-program lain yang harus dibiayai dari dana zakat.

\section{Kegiatan Pemberdayaan Ekonomi Umat di DD Farm}

Dompet Dhuafa Farm merupakan sentra ternak yang didirikan dengan menggunakan konsep pemberdayaan dengan tujuan untuk meningkatkan ekonomi mustahik. Untuk memudahkan dalam memahami kegiatan pemberdayaan di DD Farm, maka penulis membuatkan tabel berikut ini : 


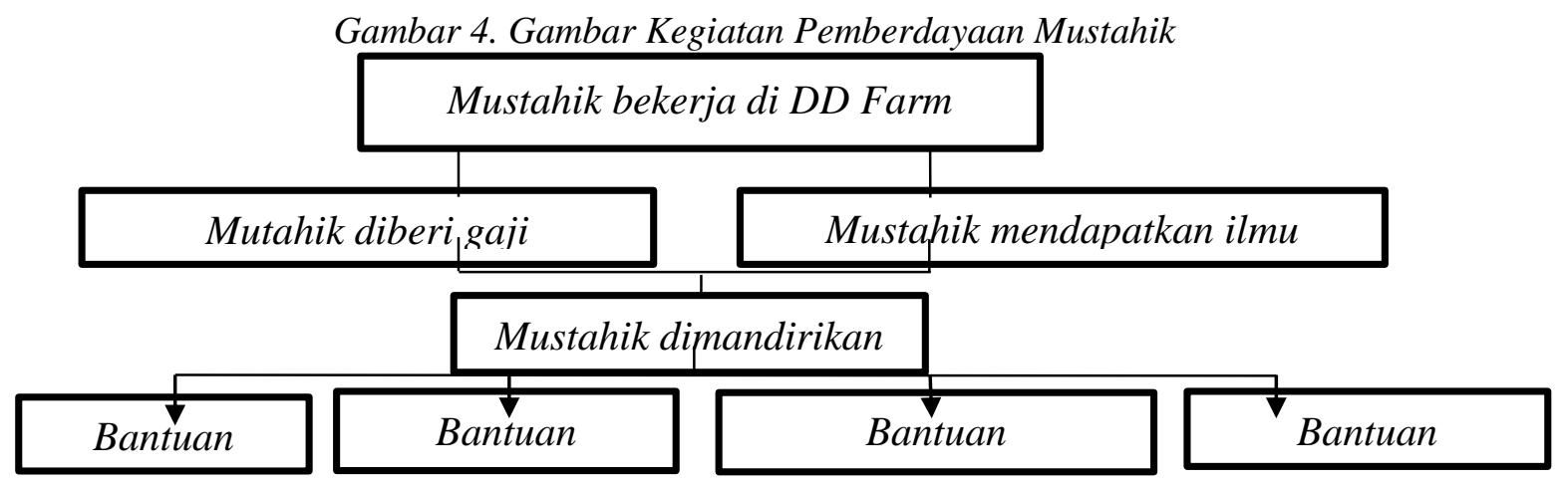

Sumber : DD Banten 2020

Mustahik yang akan diberdayakan dan menjadi sasaran lembaga Dompet Dhuafa Banten adalah mustahik yang miskin tetapi tidak menjadikan kemiskinannya sebagai mata pencaharian, dia mau merubah hidupnya jauh lebih baik. Misalnya jika ada acara sosialisasi, penyuluhan, mustahik tersebut bersemangat untuk mengikuti acaranya, mustahik seperti itulah yang menjadi sasaran Dompet Dhuafa karena potensi keberhasilannya lebih besar daripada menghabis-habiskan waktu dan tenaga serta pikiran untuk mereka yang miskinnya memang sudah menyerah yang lebih memilih untuk mengemis dijalanan.

Mustahik yang sudah lolos dari proses penyeleksian calon mustahik, selanjutnya adalah melakukan kontrak dan pembagian tugas. Mustahik yang ada di Dompet Dhuafa terbagi menjadi dua macam. Kesatu, mustahik yang berperan sebagai penerima dan pekerja DD Farm, mustahik ini disebut sebagai "penerima tetap". Kedua, mustahik yang berperan sebagai penerima manfaat namun tidak bekerja secara tetap di DD Farm, tetapi bekerja ketika ada proyek-proyek tertentu yang membutuhkan tenaga masyarakat yang lebih banyak, maka mereka akan ikut dipekerjakan. Biasanya mustahik yang bekerja di DD Farm akan ditempatkan sesuai dengan kontrak diawal dan kemudian jika para mustahik itu sudah bekerja maka selanjutnya mereka disebut dengan anak buah kandang (ABK).

Dalam pemberdayaan masyarakat Dompet Dhuafa Farm memiliki beberapa kegiatan utama, adapun kegiatan tersebut adalah sebagai berikut:

- Penggemukan (Feetening).Tujuannya adalah untuk memenuhi kebutuhan daging harian dan Qurban termasuk untuk kebutuhan-kebutuhan akikah, kebutuhan karkas untuk restoran.

- Pembibitan (Breeding) ternak domba dan kambing.Tujuannya adalah untuk meningkatkan kualitas bibit ternak yang dipelihara oleh DD Farm. Dengan adanya bibit ternak yang unggul di DD Farm maka akan meningkatkan nilai jual.

- Pembuatan pakan.Tujuannya adalah untuk mendapatkan jenis pakan yang baik dan untuk peningkatan jumlah produksi hewan ternak dengan menggunakan formulasi yang efektif serta efisien secara biaya.

- Pupuk kandang.DD Farm meluncurkan pupuk kandang sebagai program pemberdayaan ekonomi dari hasil kotoran peternakan. Pupuk itu dikemas dalam kemasan $10 \mathrm{~kg}$. Pupuk kandang yang diluncurkan oleh DD Farm ini sudah banyak dipesan oleh para petani yang ada di Banten. 
- Pengembangan DD Farm menjadi Edu Farm .Tujuannya adalah sentra ternak DD Farm ini diarahkan untuk edukasi tentang peternakan bagi masyarakat umum maupun bagi lembaga-lembaga yang hendak mengembangkan program yang sama.

Supaya para mustahik bisa bekerja dan mengurus dengan baik maka harus dilakukan pelatihan-pelatihan beternak tentang bagaimana mengurus hewan ternak dari sejak lahir dan dari sejak datang dari daerah lain. Agar para mustahik yang bekerja sambil belajar itu tercukupi kebutuhannya, maka sistemnya diberi digaji setiap bulan. Saat ini penerima manfaat tetap yang ada di DD Farm berjumlah 9 orang mustahik. Berdasarkan hasil wawancara penulis dengan mustahik, para mustahik yang bekerja sebagai anak buah kandang diberi gaji Rp. 2.100.000/bulan. Adapun untuk ketua kandang diberi gaji Rp. 2.750.000/bulan, gaji yang diterimanya itu sudah bersih tidak ada potongan apapun. Para mustahik mengaku gaji yang diterimanya sudah lebih dari cukup, gaji yang mereka dapatkan digunakan untuk memenuhi kebutuhan hidupnya sehari-hari dan memenuhi kebutuhan keluarganya.

Berdasarkan hasil wawancara dengan mustahik, mereka bekerja di DD Farm dengan kontrak selama 2 tahun dengan bagian pekerjaan yang berbeda-beda. Dalam waktu 2 tahun itu diharapkan para mustahik sudah benar-benar bisa beternak dan kemudian setelah itu mustahik akan dimandirikan dan diganti oleh mustahik yang lainnya. mustahik yang sudah bekerja dan menjalani proses pembelajaran selama 2 tahun, mereka dimandirikan kemudian diberikan bantuan, yaitu sebagai berikut :

- Bantuan modal.Salah satu aspek permasalahan yang dihadapi oleh masyarakat adalah permodalan. Oleh karena itu mustahik yang di mandirikan akan diberikan bantuan modal berupa beberapa ekor domba/kambing untuk di gemukan.

- Bantuan Pembangunan Kandang. Permasalahan berikutnya bagi masyarakat adalah terbatasnya modal untuk membuat kandang, padahal peternakan merupakan usaha yang memerlukan perawatan khusus supaya hewan ternak terjaga, mengingat hewan seperti domba/kambing sangat rentan terhadap kondisi cuaca serta kandang yang steril untuk mencegah berbagai penyakit sehingga hewan ternak senantiasa fit.

- Bantuan Pendampingan.Meskipun selama mustahik bekerja di DD Farm sudah mendapatkan ilmu tentang beternak, pendampingan mustahik yang dimandirikan memang perlu dan penting, sebab kemungkinan tidak semua permasalahan yang mereka hadapi sudah mampu mereka atasi sendiri.

- Bantuan Kemitraan.Mustahik yang bekerja di DD Farm pada umumnya tingkat pendidikannya rendah, mereka tidak paham digital, belum mengerti bagaimana strategi promosi, komunikasi, dan marketing.

Selain memberdayakan mustahik yang bekerja langsung di DD Farm, secara tidak langsung DD Farm juga memberdayakan masyarakat sekitar Kp. Gowok, Contohnya ada 5 orang yang mencacah jagung untuk dijadikan silase, kemudian ada ibu-ibu yang bertugas untuk mengemas silase yang sudah jadi.

Dari penjelasan di atas penulis dapat menyimpulkan bahwa dengan adanya pengelolaan wakaf secara produktif dengan model pengembangan peternakan domba dan 
kambing yang dikelola dengan konsep memberdayakan masyarakat. Banyak masyarakat yang ikut terbantu, sehingga perekonomian masyarakat setempat dapat meningkat.

\section{Pendistribusian Hasil Pengelolaan Wakaf Produktif DD Farm}

Hasil pengelolaan wakaf produktif DD Farm di distribusikan untuk programprogram mustahik, yaitu program pendidikan, ekonomi, kesehatan, dan sosial kemanusiaaan. Adapun penjelasan keempat program tersebut adalah sebagai berikut :

- Pendidikan. Dompet Dhuafa Banten mengelola Sekolah Dasar Kreatif (SD Kreatif). Sekolah ini dibangun di lahan wakaf yang sama dengan DD Farm yang luasnya $8000 \mathrm{~m}^{2}$, letaknya berbatasan dengan pondok pesantren Solemaniyah Kp. Gowok. SD Kreatif ini adalah sekolah yang diperuntukan bagi kaum dhuafa sehingga tidak dikenakan bayaran.

- Ekonomi. Pemberdayaan ekonomi merupakan salah satu usaha memampukan dan memandirikan kehidupan perekonomian masyarakat tersebut. Masyarakat berperan penting dalam membangun kesejahteraan sosial. Pengelolaan dan pengembangan wakaf produktif di DD Farm menjadi pilar atau penopang ekonomi.

- Kesehatan. Selain untuk memberikan kesejahteraan dalam segi ekonomi, hasil dari pengelolaan wakaf produktif DD Farm di Kp. Gowok disalurkan juga untuk memberikan pendampingan serta pelayanan kesehatan cumacuma kepada masyarakat sekitar, khususnya warga Kp. Gowok dan sekarang ini Kp. Gowok menjadi kampung yang bebas Corona.

- Sosial Kemanusiaan. Dalam pendistribusian hasil pengelolaan wakaf produktif di DD Farm, ada porsi yang didistribusikan untuk sosial kemanusiaan. Kemudian ada pola di lembaga zakat, bahwa satu hal yang memang pertama kali harus diperhatikan yaitu bagi kaum dhuafa yang tidak bisa diberdayakan seperti lansia, disabilitas, dan orang-orang yang kelaparan.

\section{Evaluasi Keberhasilan Kegiatan Pemberdayaan Ekonomi DD Banten}

Berdasarkan hasil penelitian yang sudah peneliti lakukan tentang pemberdayaan masyarakat di Dompet Dhuafa Banten sudah mencakup kesembilan indikator tersebut. Adapun penjelasan indikator-indikatornya adalah sebagai berikut :

- Indikator Ketersediaan. Indikator ini melihat apakah unsur yang seharusnya ada dalam suatu proses itu benar-benar ada. Unsur-unsur dalam program pemberdayaan masyarakat dari DD Banten benar-benar ada yaitu dari pihak DD Banten sebagai pengelola program pemberdayaan, kemudian sentra ternak DD Farm dikelola oleh Bapak Latif sebagai sebagai pihak yang dianggap berkompeten untuk memberikan pelatihan kepada sasaran pemberdayaan, dalam studi kasus ini sasaran pemberdayaannya adalah masyarakat kaum dhuafa yang berada di Link. Kp. Gowok.

- Indikator Relevansi. Indikator ini menunjukan seberapa relevan atau tepatnya suatu teknologi atau layanan yang ditawarkan. Ditinjau dari indikator ini, program pemberdayaan wakaf produktif yang dilaksanakan 
oleh DD Banten sudah relevan dengan memberikan layanan berupa bantuan-bantuan kepada sasaran pemberdayaan yakni para mustahik yang bekerja di DD Farm. Dapat dikatakan relevan karena bantuan-bantuan yang diberikan dapat dijadikan sarana untuk memandirikan para mustahik secara berkelanjutan.

- Indikator Keterjangkauan. Indikator ini melihat apakah layanan yang ditawarkan masih berada dalam jangkauan pihak-pihak yang membutuhkan. Hasil dari observasi yang telah dilakukan oleh peneliti menunjukan bahwa layanan yang diberikan kepada para penerima manfaat dapat dijangkau oleh pihak yang membutuhkan

- Indikator Pemanfaatan. Indikator ini melihat seberapa banyak suatu layanan yang diberi pihak pemberi layanan diterapkan atau dimanfaatkan kelompok sasaran. Fakta dilapangan menunjukan indikator ini sudah terpenuhi, melihat bagaimana para sasaran pemberdayaan yaitu penerima manfaat tetap yang sudah dimandirikan dapat melakukan pengelolaan ternaknya dengan baik karena sudah dibekali ilmu tentang beternak serta mendapat pendampingan.

- Indikator Cukupan. Indikator ini menunjukan proporsi orang-orang yang membutuhkan sesuatu dan menerima layanan tersebut. Proporsi dalam program wakaf produktif ini ditentukan oleh pihak DD Banten, karena mereka berpegang pada konsep pemberdayaan ekonomi, yang mana proporsi pemberian layanan tentu merupakan hasil dari seleksi yang ketat dari pihak DD Banten selaku pengelola wakaf produktif.

- Indikator Kualitas. Indikator ini menunjukan kualitas dari layanan yang disampaikan ke kelompok sasaran. Kualitas layanan yang diberikan DD Banten kepada para penerima manfaat dapat diberikan nilai secara baik. Karena layanan berupa pemberian bantuan-bantuan akan memberikan dampak yang luas dan berguna bagi para penerima manfaat.

- Indikator Upaya. Indikator ini menggambarkan beberapa banyak upaya yang sudah ditanamkan dalam rangka mencapai tujuan. Tujuan mengelola wakaf secara produktif dengan konsep pemberdayaan masyarakat di DD Banten ini sendiri adalah untuk memandirikan dan meningkatkan perekonomian masyarakat.

- Indikator Efisiensi. Indikator ini menunjukan apakah sumber daya dan aktivitas yang dilaksanakan guna mencapai tujuan dimanfaatkan secara efisien, atau tidak memboroskan sumber daya yang ada dalam mencapai tujuan. Tingkat efisiensi yang dilakukan oleh DD Banten dalam program wakaf produktif yaitu pemberdayaan masyarakat sudah optimal karena mereka memiliki perencanaan yang jelas sebelum melakukan pengelolaan, melakukan riset-riset dalam pengelolaan sentra ternak agar mendapatkan efisiensi dalam penggunaan sumber daya yang ada, dan proyeksi keuangan yang tepat serta pemilihan sasaran pemberdayaan yang tepat sasaran.

- Indikator Dampak. Indikator ini melihat apakah sesuatu yang dilakukan oleh pihak pemberi layanan benar-benar memberikan sesuatu perubahan. Dampak perubahan yang ada di DD Banten dengan melakukan 
pengelolaan wakaf produktif dengan konsep pemberdayaan ekonomi umat dapat dilihat dari para mustahik yang yang bertindak sebagai penerima tetap. Mereka diperkerjakan di DD Farm dan kemudian diberi gaji dan pengetahuan.

Dari penjelasan di atas dapat disimpulkan bahwa pemberdayaan ekonomi umat di Dompet Dhuafa Banten sudah dapat dikatakan baik, karena sudah sesuai dengan indikator-indikator yang peneliti gunakan dalam penelitian ini.

\section{Analisis Peluang dan Hambatan Pengelolaan Wakaf Produktif}

Dalam wakaf produktif ada beberapa faktor yang menjadi peluang dan hambatan pengelolaan dan pengembangan wakaf tersebut.

Faktor Peluang dan Hambatan Internal

Faktor peluang internal merupakan faktor yang menjadi peluang berkembangnya Dompet Dhuafa Farm (DD Farm) Banten yang dilihat dari sisi dalam lembaganya. Adapun yang menjadi faktor peluang internal tersebut adalah sebagai berikut :

- Mendirikan Edu Farm. Pariwisata merupakan salah satu hal yang penting bagi suatu negara. Dengan adanya pariwisata, suatu negara atau lebih khusus lagi pemerintah daerah tempat obyek wisata itu berada mendapat pemasukan dari pendapatan setiap obyek wisata.

- Pengembangan bisnis DD Farm. Sentra ternak Dompet Dhuafa Farm Banten memiliki beberapa pengembangan bisnis yang dapat menambah profit. Diantaranya sebagai berikut :

- Pembuatan pupuk kandang hasil kotoran hewan ternak.

- Pembuatan pakan hewan yang berkualitas.

- Unit usaha nasi kebuli Laziz.

- Tebar hewan qurban.

- Unit usaha Aqiqahku.

- Membuat restoran DD Farm

- Memiliki sistem manajerial yang baik. Dompet Dhuafa merupakan lembaga amil zakat yang melakukan pengelolaan secara modern dan profesional. Hal itu menjadi salah satu sistem yang dipegang teguh oleh para amil Dompet Dhuafa. Karena dengan berpegang teguh pada kedua prinsip tersebut, masyarakat bisa terus mempercayakan dana kebajikannya kepada lembaga ini.

Faktor hambatan internal pengelolaan dan pengembangan wakaf produktif di Dompet Dhuafa Banten, sebagai berikut:

- Tata letak DD Farm. Lahan DD Farm termasuk lahan marginal, lokasi DD Farm yang dekat dengan Kawasan Pusat Pemerintahan Provinsi Banten (KP3B), sehingga jika dijadikan peternakan murni maka akan menimbulkan permasalahan. Selain itu dekat juga dengan rumah-rumah warga sehingga perlu dipikirkan dampak yang mungkin saja terjadi. 
- Pencarian pasar atau market. Dompet Dhufa dalam mendistribusikan hewan ternak domba dan kambing mengalami hambatan karena susahnya mencari pasar atau market. Karena untuk mencari pasar membutuhkan strategi dan bisnis turunannya yang dapat menyerap penjualan domba dan kambing.

- Penerimaan harta benda wakaf. Penerimaan harta wakaf yang diterima oleh Dompet Dhuafa Banten seringkali hanya berupa tanah saja tidak dibarengi dengan pemberian modal. Sehingga tanah wakaf yang diberikan oleh wakif tersebut ditahan terlebih dahulu tidak bisa langsung digunakan baik untuk kegiatan produktif maupun non-produktif dan bahkan jika lokasi lahan wakafnya susah untuk diproduktifkan maka lembaga akan menolaknya.

- Minimnya sumber dana. Salah satu hambatan dalam pengelolaan wakaf produktif di Dompet Dhuafa Banten adalah minimnya sumber dana. Sehingga program-program pengelolaan wakaf produktif yang sudah direncanakan banyak yang belum bisa direalisasikan.

- Minimnya sumber daya manusia. Salah satu hal yang menjadi penghambat dalam pengelolaan dan pengembangan wakaf produktif di DD Banten yaitu sumber daya manusia yang terbatas hanya berjumlah 10 orang. Dari 10 orang tersebut mengurusi program-program untuk satu provinsi, sementara untuk mengembangkan wakaf produktif membutuhkan orang yang fokus.

- Minimnya skill. Sumber daya manusia atau pegawai yang berasal dari mustahik memiliki keterbatasan skill dalam pengelolaan peternakan. Sehingga ketika mereka dipekerjakan di Dompet Dhuafa Farm mengalami kesulitan-kesulitan hal itu dikarenakan mustahik tidak mempunyai latar belakang sebagai peternak domba dan kambing.

\section{Faktor Peluang dan Hambatan Eksternal}

Faktor peluang ekstrenal merupakan faktor yang menjadi peluang berkembangnya Dompet Dhuafa Farm Banten yang dilihat dari sisi luar lembaganya. Adapun yang menjadi faktor peluang internal tersebut adalah sebagai berikut:

Kebutuhan pasar kambing dan domba yang masih sangat besar, sementara pemasoknya kecil. Sehingga ini menjadi peluang dalam pengembangan pengelolaan DD Farm.

Provinsi Banten memiliki tanah wakaf yang cukup banyak. Sehingga jika lembaga memiliki dana untuk memproduktifkan tanah-tanah wakaf tersebut, maka lembaga tinggal bekerjasama dengan yang memiliki tanah wakaf tersebut.

Banyak masyarakat yang mau mewakafkan lahan tanah ke Dompet Dhuafa Banten untuk di produktifkan. Hal itu menjadi peluang bagi Dompet Dhuafa Banten dalam melakukan pengembangan pengelolaan wakaf produktif.

Faktor hambatan eksternal pengelolaan dan pengembangan wakaf produktif di Dompet Dhuafa Banten, sebagai berikut: 
Masih minimnya pengetahuan masyarakat terhadap wakaf produktif, kebanyakan masyarakat hanya mewakafkan tanah. Sehingga pembangunan dan pengembangan wakaf produktif pun terhambat.

Susahnya mencari pengadaan bakalan domba dan kambing, karena sekarangsekarang ini pengadaan bakalan itu langka. Disamping itu tidak hanya langka tetapi harganya juga cukup mahal, sehingga ini menjadi penghambat dalam program pengembangan.

Masyarakat masih enggan untuk berwakaf uang. Hal itu dapat dilihat ketika Dompet Dhuafa Banten melakukan penghimpunan wakaf uang untuk pembebasan lahan wakaf, penghimpunan yang dilakukan selama satu tahun itu masih jauh dari pencapaian target.

Belum adanya investor. Dalam waktu dekat ini Dompet Dhuafa Banten membutuhkan sejumlah dana untuk membuka lini usaha. Jika lini usaha tersebut sudah terealisasi dan sudah berjalan diperkirakan akan mendapatkan profit yang cukup besar.

Demikian peluang dan hambatan internal, serta peluang dan hambatan eksternal dalam pengelolaan wakaf produktif di Dompet Dhuafa Banten. Apabila faktor-faktor itu dapat dimaksimalkan dan diminimalisir, maka untuk memberdayakan masyarakat juga akan sangat terbuka lebar, sehingga banyak masyarakat khususnya kaum dhuafa yang terbantu dari segi ekonomi maupun yang lainnya.

\section{Solusi Mengatasi Hambatan Internal dan Eksternal}

Adapun solusi yang dihadirkan oleh Dompet Dhuafa Banten dalam mengatasi hambatan internal adalah sebagai berikut:

Berkaitan dengan lahan yang marginal, maka Dompet Dhuafa Banten melakukan pengurugan dan penanaman pohon yang susuai dengan karakteristik tanah, serta dibuat saluran air agar tidak terjadi banjir. Dengan tata letak lokasi yang ada, maka Dompet Dhuafa Banten menjadikan DD Farm sebagai Edu Farm yaitu tempat edukasi wisata peternakan domba dan kambing, serta melakukan pendekatan dengan masyarakat dan tokoh masyarakat, dan mencoba mengajak mereka untuk ikut bekerjasama dalam upaya meningkatkan perekonomian mustahik.

Untuk mencari pasar maka dibuat pengembangan unit-unit bisnis turunan yang bisa menyerap domba dan kambing di DD Farm. DD Banten selain mencari pasar yang berasal dari luar, DD Banten juga mencari pasar yang berasal dari internal misalnya membuat restoran yang menyediakan aneka masakan daging domba dan kambing. Pasar yang berasal dari internal itu akan memudahkan pembayaran dan lain sebagainya.

Mensosialisasikan kepada pewakif jika ingin berwakaf tanah baiknya di sertai dengan berwakaf dana, paling tidak ada dana untuk modal awal. Jika dananya sudah ada maka akan mempermudah dalam pengelolaan.

Berkaitan dengan pendanaan, lembaga Dompet Dhuafa Banten akan terus mengkampanyekan kepada masyarakat baik melalui media sosial maupun mengiklankannya supaya masyarakat tertarik untuk berdonasi dan berwakaf di Dompet Dhuafa Banten.

Melakukan perekrutan sumber daya manusia yang sesuai dengan kebutuhan lembaga. Dengan melakukan rekrutmen tersebut akan mendapatkan sumber daya 
manusia yang sesuai dengan apa yang dibutuhkan oleh lembaga. Sehingga pengembangan pengelolaan wakaf produktif di DD Banten dapat terlaksana dengan baik. Farm.

Memberikan pengajaran lebih masif lagi kepada mustahik yang bekerja di DD

Adapun solusi hambatan eksternal yang dihadirkan oleh Dompet Dhuafa Banten adalah sebagai berikut

Melakukan sosialisasi kepada masyarakat tentang wakaf produktif. Dengan demikian diharapkan masyarakat dapat mengatahui tentang wakaf produktif sehingga banyak masyarakat yang berwakaf secara produktif.

Untuk pengadaan bakalan sejauh ini solusinya yaitu dengan membeli dari masyarakat-masyarakat sekitar secara perorangan, yang sebelumnya lembaga membelinya dari peterenakan besar, dikarenakan peternakan besarnya sedang langka maka dikumpulkan dari penduduk-penduduk yang mempunyai misalnya 1 ekor, 2 ekor, dan 3 ekor lalu dibeli kemudian dikumpulkan, setiap seminggu sekali akan dijemput ke tempat tersebut.

Melakukan penghimpunan dengan lebih masif lagi. Sehingga program-program yang sudah ada di Dompet Dhuafa Banten dapat terealisasi.

Dana zakat diberlakukan sebagai investor dan yang berhak mendapatkan dana bagian investasinya adalah mustahik. Di satu sisi lembaga Dompet Dhuafa Banten juga mencari investor yang mau bekerjasama serta se-visi dan se-misi. Sehingga terjalin keterpaduan kepentingan antara DD Banten dengan para Investor

\section{KESIMPULAN}

Berdasarkan hasil penelitian, peneliti memperoleh kesimpulan dari penelitian mengenai Strategi Pengelolaan Wakaf Produktif Dalam Rangka Pemberdayaan Ekonomi Umat (Studi Kasus : Wakaf Produktif Dompet Dhuafa Banten), yaitu sebagai berikut :

Dompet Dhuafa Banten dalam melakukan kegiatan pengelolaan wakaf produktif terdapat 4 strategi, yaitu : Pertama, mendirikan Dompet Dhuafa Farm karena di Provinsi Banten memiliki potensi yang besar disentra ternak domba dan kambing. Kedua, dalam pengelolaannya melibatkan orang yang ahli dibidangnya dalam hal ini orang yang ahli dalam bidang peternakan. Ketiga, mencari bisnis-bisnis turunan dari peternakan ini, untuk dijadikan penghasilan tambahan agar surplusnya bisa diberikan ke penerima manfaat secara luas. Keempat, meningkatkan kompetensi sumber daya manusia (SDM) di lembaga Dompet Dhuafa Banten, sehingga pengelolaan wakaf produktif dapat dengan maksimal. Strategi-strategi yang diterapkan oleh DD Banten tersebut sudah berhasil dalam meningkatkan perekonomian masyarakat serta dapat menjaga keutuhan harta benda wakaf.

Program pemberdayaan ekonomi yang dilakukan oleh DD Banten sudah berhasil meningkatkan perekonomian mustahik, karena mustahik yang diberdayakan selain mendapatkan ilmu tentang beternak juga mendapatkan gaji setiap bulannya. Mustahik yang sudah bekerja selama 2 tahun akan dimandirikan. Mustahik yang dimandirikan tersebut mendapatkan bantuan modal, bantuan pembangunan kandang, bantuan pendampingan dan bantuan kemitraan. Profit yang didapatkan dari pengelolaan wakaf 
produktif ini disalurkan untuk program-program mustahik yaitu program pendidikan, ekonomi, kesehatan, dan sosial kemanusiaan.

Kegiatan pengelolaan wakaf produktif di DD Banten terdapat peluang dan hambatan baik internal maupun eksternal. Peluang internalnya yaitu mendirikan Edu Farm, pengembangan unit bisnis DD Farm, miliki sistem manajerial yang baik. Hambatan eksternalnya yaitu tata letak DD Farm, pencarian pasar atau market, penerimaan harta benda wakaf hanya berupa tanah saja tidak dibarengi dengan pemberian modal, minimnya sumber dana, minimnya SDM, minimnya skill para mustahik. Adapun peluang eksternalnya yaitu kebutuhan pasar terhadap domba dan kambing yang cukup besar, Provinsi Banten memiliki aset tanah wakaf yang cukup banyak, selain itu banyak warga yang mewakafkan tanahnya ke DD Banten untuk diproduktifkan. Hambatan eksternalnya yaitu masih minimnya pengetahuan warga terhadap wakaf produktif, susahnya mencari pengadaan bakalan domba \& kambing, masyarakat masih enggan untuk berwakaf uang, dan belum adanya investor. Peluang-peluang dalam kegiatan pengelolaan wakaf produktif ini sudah mampu dikelola dengan baik oleh DD Banten. Sedangkan hambatanhambatannya sudah mampu diantisipasi dan diminimalisir.

\section{REFERENSI}

Assauri. 2013. Strategic Management. Jakarta: PT Raja Grasindo Persada.

Handayani, Dini. 2011. Pengelolaan Wakaf Uang Di Indonesia. Banten: Dinas Pendidikan Provinsi Banten.

Hadyantari, Faizatu Almas. 2018. Pemberdayaan Wakaf Produktif: Upaya Strategis untuk Kesejahteraan Ekonomi Masyarakat. MEIS. Volume 6(1), 1-22.

Julita dan Eka Nurmala Sari. 2015. Strategi Generik Porter Bagi UMKM Dalam Menghadapi Masyarakat Ekonomi Asean (MEA) (Studi Kasus: Pada UMKM di Kabupaten Deli Serdang). SNEMA. ISBN : 978-602-17129-5-5

Mubarok. 2013. Model Pengembangan Wakaf Produktif. Jurnal Hukum Islam. Volume 11(1), 19-33.

Munir, Akhmad Sirojudin. 2015. Optimalisasi Pemberdayaan Wakaf Secara Produktif. Jurnal Ummul Qura, Volume 6(2), 94-109.

Nawawi, M. Anwar. 2016. Pengembangan Wakaf Uang Tunai Sebagai Sistem Pemeberdayaan Umat dalam Pandangan Ulama Konvensional dan Kontemporer. Fikri, Volume 1(1), 183-210.

Nasution dan Hasanah. 2005. Wakaf Tunai Inovasi Finansial Islam (Peluang dan Tantangan dalam Mewujudkan Kesejahteraan Umat). Jakarta: Pusat Kajian Timur Tengah dan Islam Universitas Indonesia.

Suryadi, Niryad. 2017. Strategi Pengelolaan Wakaf Produktif Dalam Rangka Pemberdayaan Umat Di Kecematan Pangkajene Kabupaten Pangkep. Skripsi. UIN Alauddin Makassar: tidak diterbitkan

Rangkuti, Freddy. 2014. Analisis SWOT Teknik Membedah Kasus Bisnis. Jakarta: PT Gramedia Pustaka Utama.

Rozalinda. 2015. Manajemen Wakaf Produktif. Jakarta: Raja Grafindo Persada. 
Sarinah, Iin, Aan Anwar Shihabudin dan Erlan Suwarlan. 2019. Pemberdayaan Masyarakat Dalam Bidang Ekonomi Oleh Pemerintah Desa Pangandaran Kecamatan Pangandaran Kabupaten Pangandaran. Jurnal Moderat. Volume 5(3), 267-277.

Sopiah. 2018. Management Sumber Daya Manusia Strategic. Yogyakarta: ANDI

Sugiyono. 2017. Meode Penelitian Kuantitatif, Kualitatif, dan R\&D. Bandung: Alfabeta.

Waluya, Atep Hendang. 2018. Istibdal Wakaf Dalam Pandangan Fukaha Klasik Dan Kontemporer. Misykat al-Anwar Jurnal Kajian Islam dan Masyarakat. Vol 29, No 2 (2018). 51

Yulma, Nur Liviasari dan Sri Herianingrum. 2016. Peran Wakaf Tunai (Studi Kasus Pada BMT Amanah Ummah Surabaya). Jurnal Ekonomi Syariah Teori dan Terapan. Vol. 3(11), 856-871.

http://siwak.kemenag.go.id, diakses pada tanggal 25April 2020 